\title{
The paths to last in pastoral sheep farming in the Cevennes in France
}

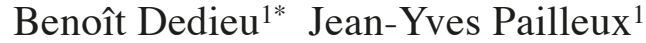

\section{Keywords}

Sheep, farming system, adaptation, sustainable livelihoods,

Mediterranean region

Accepted: 21 December 2014; Published: 25 March 2016

\begin{abstract}
Summary
In a context of uncertainty of future conditions, which are the sustainable paths? We described the long-term action logics relied upon by the farmers to develop their farms or adapt them to their environment. These logics are based on choices related to increasing the farm size, specializing, the techniques used, marketing, production project debts, and technology incorporation. The data comes from sheep farms in the Cevennes, a pastoral Mediterranean region of Southern France, based on trajectory surveys of families, farming, and sheep management over 30 years (1982-2012). Although sheep farming hardly changed over this period, three different long-term action logics were identified: a clannish logic that gives the opportunity for the children to settle on the farm or nearby; a logic centered on sheep tradition with a focus on increasing the herd size; a multiphase logic, i.e. two or three successive sheep management types or combined household activities are explored. The identified action logics were similar to those described in other studies, except that they did not include logics based on increasing herd productivity by use of technologies, an option too removed from the kind of pastoralism practiced in the Cevennes.
\end{abstract}

- How to cite this article: Dedieu B., Pailleux J.-Y., 2015. The paths to last in pastoral sheep farming in the Cevennes, France. Rev. Elev. Med. Vet. Pays Trop., 68 (2-3): 87-92

\section{INTRODUCTION}

Because of unpredictable global markets, policy changes, and increasing climatic disturbances, livestock farmers must plan their systems and their dynamics by integrating uncertainty about future conditions if they are to hold firm. The vulnerability (Chambers, 2006) of farming systems and the abruptness of changes seem greater in the South, because of weak mechanisms and the absence of any kind of incentives, in particular protection or regulation policies. But action under uncertainty (Lemery et al., 2005) is also the subject of increasing questioning in the North, including Europe, because of evolutions in the Common Agricultural Policy and vagueness about the reforms to come. Under these conditions of uncertainty, on what bases can farmers hold on in agriculture, how can they last?

\footnotetext{
1. Institut national de la recherche agronomique, UMR 1273 Metafort, Theix 63122 Saint Genes Champanelle, France.

* Corresponding author

Email: dedieu@clermont.inra.fr
}

The question of the "paths to last" has been producing a great deal of literature not only in the agricultural sector, but also beyond agriculture in the corporate world (e.g. Mignon, 2001). The concept of "path of development" (Evans, 2009) gave rise to many variations in the field of analysis of farming system dynamics. Structural evolutions, production orientations and technical configurations are formalized (Cialdella et al., 2009; Moulin et al., 2008; Ryschawy et al., 2012). In some of these studies, explicit account is taken of links to the farming family (Rueff et al., 2011), the dynamic of change in systems of activities, collectives and forms of work organization, with vertical (family line) and horizontal (the couple) methods of family influence on structural and technical evolutions (Terrier, 2013; Terrier et al., 2012). Another approach consists of updating the principles and their combinations (long-term action logics) on which farmers rely to develop their farms in their own context (Dedieu, 2009). These principles can be expressed as elements of a deliberate or emerging (Moulin et al., 2001) strategy of farm evolution patterns.

The present article is in line with this second approach which gave rise to variations in different livestock farming regions in France and South America (Argentina, Uruguay) (Dedieu and Ingrand, 2010; Levrouw et al., 2007). We have been interested in the long-term action logics of sheep farmers in the Cevennes, a 
Mediterranean mountain region of the South of France (less than 100 kilometers from Montpellier) where pastoral sheep farming is still practiced. Firstly, we presented the analysis framework of the principles / action logics and described the research project. Secondly, results (the action logic typology), and similarities and differences with previous studies were discussed, as well as the impact of territorial characteristics on the dynamics observed.

Taking inspiration from the concepts of flexibility and resilience and their application in dynamic approaches to farming systems (Darnhofer et al., 2012; Milestadt et al., 2012), several studies (Begon et al., 2009; Lemery et al., 2005; Lewrouw et al., 2007) highlighted five sets of principles which farmers put forward to explain and justify the continuities and disruptions of their farm evolution patterns. These principles are fields of expression of what it is advisable to do to last. In their variety, they are subjects of controversy among farmers. These sets of principles are:

- Configuration of the family farm system with two principles relative to i) the size, "being big to hold firm" or on the contrary "getting big isn't for me, you get lost in the process", and ii) the combination of activities, opposing diversification, "not all the eggs in one basket", and specialization "being competent and effective";

- Financial or technical risk taking, for the improvement of the system, with the three methods, i.e. "never", "necessary", "only if it's highly controlled";

- Finances, i.e. with respect to debt (never, or a necessary evil), to savings (systematic or not), to the possibility of adjusting family direct debts in a difficult year;

- Operation of the technical system and work, with three methods corresponding to the emphasis placed by the farmers on different dimensions of this operation, i) strong technical ambition ("it is the guarantee for holding firm") with work that has to follow, ii) management ambition ("what matters is optimizing all of the farm resources, including work mastered" as well as the fiscal aspect), and iii) the will to keep flexibility in the production process and in the work ("keep something in reserve", "never be at the limit");

- Socio-technical networks (information, discussion and advice enabling downstream to be controlled ("you have to invest in producers' organizations").

Boxes 1 and 2 (Dedieu and Ingrand, 2010) present the diversity of long-term action logics in Segala (Center of France, intensive dairy farming) and Uruguay (rather extensive milk and meat farms).

\section{MATERIALS AND METHODS}

\section{Sheep farming in the Cevennes}

Characteristic of the Mediterranean mountains of the south of France, the Cevennes landscape is covered in trees. Annual average rainfall in the valleys is $450 \mathrm{~mm}$ with severe summer droughts and mild autumns. Grasslands, when they exist, are located in the valley floors. Rangelands covered by old sweet chestnut groves the main resource for humans and animals in the past - and holm oaks form a significant proportion of the flock feeding resources, from 35 to $75 \%$ of the on-farm flock intake (Dedieu, 1984) including chestnut fruit in autumn and winter. They enable livestock farming to find its place in these large areas.

Transhumance of the flocks toward the high pastures during the three months of summer makes it possible to take the load off the farmstead land and limit livestock work in summer: summer flocks are shepherded in a collective way by cooperatives. Finally, a very significant part of the food resource is found directly by the flocks. In a way that varies according to the systems, only short periods in

\section{Box 1}

LONG-TERM ACTION LOGICS IN DAIRY FARMING IN THE SeGala (BeGOn ET AL., 2009)

- To be technically efficient (the indicator is the level of production per cow)

Little modification to land, fast specialization at the beginning of farm evolution pattern, partner works outside or not. Some farmers evolve with time toward administrative planning.

\section{- To be big with regard to milk production}

Increase (by accumulation) land area, quotas and livestock; tendency to specialize, in particular in dairy (even if in some phases there can be several agricultural activities). High level of performance required.

- To have a large dairy herd but also another herbivorous-related activity used as a buffer if a catastrophe occurs

Expand from the outset to include several activities at the same time but milk prevails; technical ambition concerning milk at the beginning then managerial ambition.

- To be a diversified business person: to be big with several activities of equal importance

"Doing business", not necessarily doing what is best, with several irons in the fire and each one significant.

- To diversify activities in relation to local opportunities Small structures; attempts at diversification or gathering; flexibility on dairy herd management, with no great ambition concerning the dairy production level, variable and dependent on forage resources (high degree of feed autonomy).

Box 2

\section{ACTION LOGICS IN CATTLE FARMING IN URUGUAY (LEVROUW ET AL., 2007)}

\section{- To be diversified by doing odd jobs on a local basis}

Diversification of farming activities; no expansion (land area and cattle head); no investments; continuous adjustments to activities and management patterns, with traditional (extensive) cattle management.

\section{- To become bigger}

Specialization in suckler cattle farming; expansion (herd and grassland area); investments on condition that previous savings are available; traditional extensive herd management.

\section{- To optimize the technical system}

Specialization in beef or dairy cattle farming seeking high level of animal productivity (annual milk yield per cow, calf crop per cow); debts from investment in technology; search for permanent innovation including risk taking.

\section{- Maximum control}

Milk or beef specialization seeking high level of productivity; expansion (land area and livestock); financial investments when savings are sufficient and a return clearly foreseeable. Innovation planned with cost/benefit calculation. 
the autumn or at the end of winter are concerned with the distribution of forage stocks inside. The farming activity is still very pastoral today, with lambing in early autumn and winter and light lambs produced for fattening elsewhere. But the land base is uncertain: verbal rentals predominate (verbal authorization to use rough grazing), as land under ownership or lease is rather limited.

Fine control of farming systems makes it possible to limit, even benefit from structural and land handicaps, by making good use of the diversity of existing resources. Each livestock farmer coordinates the time when sweet chestnuts and acorns become accessible with the physiological stages of the animals when they can make best use of them. In all the farms, the management organization, shepherding, batching, even blocking lambing periods make it possible to have low requirement animals or ewes building up their strength when it is hoped that the richest resources are to be found under the trees.

The size of arable land available to the farmers (from 0 to 40 hectares) has a huge effect on the livestock system operations. For some, autonomy in stored fodder is total or partial but requires equipment. For others, the topography, the low proportion of grasslands combined with a 'pocket handkerchief' type of configuration of the grasslands in the Cevennes valley floors have directed systems toward annual purchases of fodder. This forage of very good quality is composed at least partly of hay from the Pays de Crau or of alfalfa. It is distributed at the end of pregnancy or during short lactations (two months for the light lambs, three months for the ewe lambs). Fed on supplements, the lactating ewes remain indoors (winter lambing) or are shephered on grasslands or to old orchards (autumn lambing) where they can eat sweet chestnuts which have not been collected before the frost.

In many cases, fodder purchase is the main variable cost of the system. On the other hand, these farms limit their fixed (notably renting) expenses. Thus, the Cevennes are still today a region of pastoral livestock farming where livestock farmers seek to make direct and optimum use of local natural resources. But although some still base their systems on sheer pastoralism (with only a few purchases of hay) to the point of having no harvesting equipment (but also no related structural costs) and with the sale of light lambs of 14-18 kilogram live weight for fattening, others who have areas that can be mowed purchase equipment to be self-sufficient in forage. They are then more readily inclined to finish their lambs inside.

\section{Study methodology}

To treat paths to last in 2010, we carried out interviews in 12 Cevennes farms previously surveyed in $1981(\mathrm{n}=3)$ or closely monitored during a doctoral thesis between 1981 and $1983(\mathrm{n}=9$ ) (Dedieu, 1984). These comprehensive interviews aimed at reconstituting the evolution pattern of the farm (Moulin et al., 2008), the flock and its management, as well as the household activities. Recorded and transcribed, the conversations gave access to i) structural and management dynamics over nearly 30 years, ii) changes and events marking various phases of evolution of family livestock systems, and iii) action logics analyzed according to the five sets of principles detailed above. The analysis led to a collective restitution with livestock farmers in March 2011 to validate the various paths.

To describe briefly the sample in 2010 in the 12 surveyed farms, the areas used were large (from 200 to 600 hectares), the stocking rate was still very low (from 0.65 to one ewe per hectare), and shepherding was still essential to use the resources. Only two of the livestock farmers we met had put up fixed fences which surrounded a small area of their land.

\section{RESULTS}

Sheep farming systems changed very little in 30 years. In 2009, the environmental conditions still made shepherding absolutely essential, in spite of strong incentives to develop the use of fences that were given in the early 1980s. Under these conditions the size of the flocks only increased slightly for lack of sufficient manpower: it is difficult to keep more than 250 ewes in only one batch on these rough pastures under forest. Over time, breed types have been purified toward hardy local breeds (Raïole, Caussenarde, Rouge du Roussillon) without any one breed getting the upper hand.

The flocks were still managed outside for most part of the year. Brought inside for short periods in autumn or winter, the required fodder stocks were not very abundant (50-250 kilograms of hay per year and per ewe). The question of self-sufficiency in hay was still crucial however: five farmers had to expand outside the Cevennes, in the plain, but these expansions had only been temporary in four out of five cases.

Reproduction management was still mainly centered on autumn lambing in order to coordinate the progress of the physiological stage of the ewes with the possibilities of making good use of available resources: mountain pasture (gestation), grassland regrowth (lactation), sweet chestnuts and acorns (body condition rebuilding). But this coordination also sought to limit competition with the lambs from the Aveyron Roquefort region at the time when light lambs were being marketed. However, some farmers had been innovating by exploring new market niches (lambs for the Muslim feast of Aïd El Kebir paid 75\% or more than a fattened lamb), even adapting to the changing dates of this feast by changing the lambing period (from autumn to spring).

The analysis of farming pattern data highlighted the transformations of a small farm in the traditional model: i) very diversified, in which sheep were associated with other activities (e.g. goats, onions, arboriculture, country cottage rental), ii) thrifty, where "each unspent coin is a coin earned", "no loans". In three cases sheep farming had ceased (the farmer retired without a successor, the shepherd stopped the activity, the farmer had conflicts with hunters). In one case, conflicts with neighbors because of the development of Protected-Designation-of-Origin (PDO) onion crops on formerly abandoned terraces led to a drastic reduction in the flock, from more than 200 to 30 ewes. In three other cases, the farm was taken over by one of their children.

Three types of long-term logics emerged more or less distant from this model (Table I). They are illustrated by three cases of farmers in Boxes 3, 4 and 5.

- A clannish logic aimed at establishing the children in or near the farm. Over the long term, it involved developing the system on the basis of two or three significant activities with regular investments (buildings, land, equipment). Sheep farming increased, with two lambing periods. It was self-sufficient in hay and the range of products was diversified (light lambs, lambs fattened for the Aïd), the proportion of each being significantly adjustable from one year to the next.

- A logic centered on sheep tradition as the pivot activity. Enlarging the flock was generalized up to the limit of shepherding in the forest. In certain cases, shelters were built making it possible to use new areas that had been too distant from the main sheep shelters. Production was very stable and centered on the production of light lambs in most cases in autumn. 
- A logic marked by the succession of several phases with radically different bases, where very different management systems and niche markets were explored over time $(\mathrm{C} 1)$, or more generally by a profound change in the system of activities (C2) (Table I).

\section{Box 3}

\section{Box 4}

\section{A LOGIC CENTERED ON TRADITIONAL SHEEP FARMING AS THE PIVOT ACTIVITY}

"Nobody was pushing us, but to manage, we specialized. So we increased our flock numbers but within limits. There were 250 animals in the flock but if you reach 250-300, here, you pull everything out, there's erosion so you can't go beyond... and with that number of head you have a job to make ends meet... often, there are wages from an outside job which helps with family circumstances... that's how it is. "Since the 1980s, "we've only sold light lambs at forty, fifty or sixty days" and "I don't do spring lambing". He has little or no debts because "that's what makes us strong!" Gerard G. thinks he has enough equipment even if it is the "minimum". For him, "our tradition is rough grassland... that's why, concerning the economic aspect, for the time we are behind our sheep, we don't do anything else but the technical side counts. I'm serious about my work so my ewes which have two lambs are in huts, and they stay three or four days alone with their lambs... That's what takes time, organization, monitoring, all that..." In connection with marketing the autumn lambs, "I try to market all my lambs at the same time. Last year, they left on October 28th. This year, I postponed their leaving by a week because they were born a bit later at the height of lambing."
Box 5

A LOGIC MARKED BY THE SUCCESSION OF SEVERAL PHASES WITH RADICALLY DIFFERENT BASES MARKING THE EXPLORATION OF VERY DIFFERENT MANAGEMENT TYPES AND NICHE MARKETS OVER TIME

Bernard G.'s farm evolution pattern illustrates this logic: "it increased enormously when we had the GAEC [groupement agricole d'exploitation en commun, i.e. farm shared with another farmer] and then, we had up to 260 ewes and we didn't have enough... because everything went on direct sales... in 1990-91 we must have sent slightly more than 300 animals a year to the slaughterhouse. We were not just playing at it! My goodness, with GAEC, we certainly earned some money... the GAEC was earning and investing a massive amount of money. My associate's doctrine was: we must give ourselves the means to do things, and indeed we did do things, it was an entirely different dimension. When I found myself all alone, I started by liquidating what did not interest me at all, i.e. the equipment, and then what interested me less, i.e. marketing, and I kept the basic core of ewes and transhumance... All the same, I decreased quite a lot... For a long time I kept about 210 ewes, as long as I had land in Saint Julien, then I reduced the number to 170 ewes." In 2003, Bernard G. organized a new disruption in his professional path: "I had no lambs. At the time when everyone was saying you need to have out-of-season lambing, I already had a flock with out-of-season lambing, and I changed my flock back to spring lambing. A very early autumn lambing was very interesting when the lambs were sold really quite small but the longer you wait the more difficult it becomes to sell them. And then, I prefer to sell 50 lambs at $160 €$ rather than 160 lambs at $50 €$, don't you agree? Everything considered financially, I come out of it better now than before... it may seem paradoxical but that's how it is."

\section{Table I}

Changes in the number and lambing periods for the three long-term action logics in the Cevennes

\begin{tabular}{lccc}
$\begin{array}{l}\text { Type of farm } \\
\text { evolution pattern }\end{array}$ & $\begin{array}{c}\text { Num. } \\
\text { farms }\end{array}$ & $\begin{array}{c}\text { Evolution flock } \\
\text { num. (2009) }\end{array}$ & $\begin{array}{c}\text { Lambing } \\
\text { period 2009 }\end{array}$ \\
\hline Clannish & 2 & $++(350-400)$ & $\mathrm{A}++$ / S + \\
\hline $\begin{array}{l}\text { Centered on } \\
\text { traditional sheep } \\
\text { farming }\end{array}$ & 4 & $+(220-250)$ & $\mathrm{A}+++$ \\
\hline $\begin{array}{l}\text { C1: change of } \\
\text { period or type } \\
\text { of product }\end{array}$ & 2 & $=$ or $+(150-210)$ & $\mathrm{S}+++$ \\
$\begin{array}{l}\text { C2: stopped or } \\
\text { high sheep farming } \\
\text { reduction }\end{array}$ & 4 & & \\
\end{tabular}

* A: autumn; S: spring 


\section{DISCUSSION}

In these farms, we found the long-term action logics also met in other livestock farming situations (Begon et al., 2009; Lemery et al., 2005; Levrouw et al., 2007) with the notable exception of logics based on increasing herd productivity by incorporating technology. Expansion vs. herds maintained at sizes that promote controlled management of natural resources, diversification (more streamlined than before) $v s$. specialization, investment in equipment with loans $v s$. financial autonomy remained main lines for diversity of logics as reported in other studies. On the other hand striving for productivity proved to be too demanding and far removed from the sort of pastoralism practiced locally. Changes related then more to the choice of products: although a 14-18 kilogram lamb was still the dominant production, various production or marketing strategies had been emerging.

The permanent characteristics of the Cevennes territory influenced the options selected (difficult terrain, precarious but inexpensive access to land). The diversity of logics, specific to individuals, then came within a set of constraints and options which were closely linked to these permanent characteristics but also to the dynamics of the territory. Demographic dynamics such as the reduced number of farms meant that new pastoral areas had opened up. Land dynamics competing with touristic or crop activities, such as the production of PDO sweet onions on the rare grasslands where machinery can be used and on productive terraces, meant that even fewer areas could be mechanized for hay. Radical choices had to be made: either search for land outside the region (i.e. at least beyond 40 kilometers) or abandon the practice. Local

\section{REFERENCES}

Begon M., Pailleux J.Y., Joly, N., Lemery B., Dedieu B., 2009. Les chemins pour durer en élevage laitier : diversité des logiques d'action sur le long terme en Ségala. Rencontre Rech. Rumin., 16 : 105-108

Chambers R., 2006. Vulnerability, coping and policy (editorial introduction). IDS Bull., 37, doi: 10.1111/j.1759-5436.2006.tb00284.x

Cialdella N., Dobremez L., Madelrieux S., 2009. Livestock farming systems in urban mountain regions: differentiated paths to remain in time. Outlook Agric., 38 (2): 127-135

Darnhofer I., Gibbon D., Dedieu B., 2012. Farming systems research: An approach to inquiry. In: Farming systems research into the $21 \mathrm{st}$ Century: The new dynamic (Eds. Darnhofer I., Gibbon D., Dedieu B.). Springer, 3-31

Dedieu B., 1984. L'élevage ovin sur parcours méditerranéen : adaptation et mutation des systèmes d'élevage en Cévennes gardoises. Thèse Doct., INA, Paris-Grignon, France, 381 p.

Dedieu B., 2009. Qualification of the adaptative capacities of livestock farming systems. Rev. Bras. Zootec., 38: 397-404

Dedieu B., Ingrand S., 2010. Incertitude et adaptation : cadres théoriques et application à l'analyse de la dynamique des systèmes d'élevage. Prod. Anim., 23 (1) : 81-90

Evans N., 2009. Adjustment strategies revisited: Agricultural change in the Welsh marshes. J. Rural Stud., 25: 217-230

Lemery B., Ingrand S., Dégrange B., 2005. Agir en situation d'incertitude : le cas des éleveurs de bovins allaitants. Econ. Rurale, 288 : 57-69

Levrouw F., Morales H., Arbeletche P., Malaquin I., Tourrand J.-F., Dedieu B., 2007. Estrategias de largo plazo de los ganaderos uruguayos en situationes de incertitumbre. Agrociencia, 11 (2): 87-93 politics, in particular the retention of the local slaughterhouse ran counter to the general policy concentrating slaughterhouses and made it possible for some farmers to launch out into lamb production for the Aïd festival.

\section{CONCLUSION}

Cevennes sheep farming systems have changed very little in 30 years and remain very similar to those in the 1980s. But livestock farming is still under pressure from other users of the area. Tourism and town planning have had a powerful effect on basic grasslands but the situation has somewhat settled down. Onion cultivation on terraces has been supporting some livestock farms as another source of income but in one case it restricted the area used by the ewes causing a reduction in the flock. The hunters must still be accounted with and contacted for space use. In one case, cohabitation with other users degenerated into conflict until the livestock farm disappeared. Lastly, the necessity of shepherding the flock because of the predominant way of using land (verbal authorization) questions the young generations: to be a shepherd is to have a very specific occupation, a pastoral skill, and a relationship with the animals and the flock. But it is also a lifestyle out of step with today's living trends.

\section{Acknowledgments}

We thank the twelve farmers who agreed to meet us. Financial support from the ANR 2010 STRA-005-01 MOUVE project is also acknowledged.
Mignon S., 2001. Stratégie de pérennité d'entreprise. Vuilbert, Paris, France, $218 \mathrm{p}$.

Milestadt R., Dedieu B., Darnhofer I., Bellon S., 2012. Farms and famers facing change: the adaptive approach. In: Farming systems research into the 21st Century: The new dynamic (Eds. Darnhofer I., Gibbon D. Dedieu B.). Springer, 365-385

Moulin C., Girard N., Dedieu B., 2001. L'apport de I'analyse fonctionnelle des systèmes d'alimentation. Fourrages, 167 : 337-363

Moulin C.-H., Ingrand S., Lasseur J., Madelrieux S., Napoleone M., Pluvinage J., Thenard V., 2008. Comprendre et analyser les changements d'organisation et de conduite de l'élevage dans un ensemble d'exploitations : propositions méthodologiques. In L'élevage en mouvement : flexibilité et adaptation des exploitations d'herbivores (éds. Dedieu B., Chia E., Leclerc B., Moulin C., Tichit M.). Quae, France, 143-161.

Rueff C., Choisis J.P., Balent G., Gibon A., 2012. A preliminary assessment of the local diversity of family farms change trajectories since 1950 in a Pyrenees Mountains area. J. Sustain. Agric., 36 (5): 564-590

Ryschawy J., Choisis N., Choisis J.-P., Gibon A., 2012. Paths to last in mixed crop-livestock farming: lessons from an assessment of farm trajectories of change. Animal, doi: 10.1017/S175173111200209

Terrier M., 2013. Réalités de l'exploitation agricole familiale au prisme du temps long. Proposition $d^{\prime} u n$ cadre d'analyse interdisciplinaire et illustrations en exploitations d'élevage bovin lait dans le Vercors. Thèse Doct., Abies Irstea/Inra, France, 448 p.

Terrier M., Madelrieux S., Dufour A., Dedieu B., 2012. Saisir la diversité des formes d'articulation entre famille et exploitation : une grille de lecture. Rev. Agric. Environ. Studi., 93 (3) : 299-322 


\section{Résumé}

Dedieu B., Pailleux J.-Y. Les chemins pour durer en élevage ovin pastoral des Cévennes

Quels sont les chemins pour durer dans un contexte d'incertitude sur les conditions du futur? Les logiques d'action sur le long terme sur lesquelles les éleveurs s'appuient pour développer ou adapter leur ferme dans leur contexte propre ont été décrites. Ces logiques renvoient à des choix relatifs au dimensionnement de l'activité agricole, à la spécialisation, aux choix techniques et commerciaux, au rapport à l'endettement et à l'incorporation de technologies. Les données provenaient d'élevages ovins des Cévennes, région pastorale méditerranéenne du sud de la France, à partir de relevés de trajectoires d'évolution des familles, des activités agricoles et de la conduite du troupeau ovin sur 30 ans (1982-2012). Si I'élevage ovin n'a pas vraiment changé dans ses dimensions techniques pendant cette période, trois logiques d'action sur le long terme ont été distinguées : une logique clanique qui donne l'opportunité d'une installation des enfants dans la ferme ou à proximité d'elle ; une logique centrée sur l'activité ovine avec un agrandissement du troupeau; et une logique multiphase avec l'exploration successive de deux ou trois formules de conduite du troupeau ou de combinaison d'activités du ménage. Les logiques d'action identifiées ont été semblables à celles décrites dans d'autres études, si ce n'est qu'elles n'ont pas mis en avant de logique fondée sur l'accroissement de la productivité du troupeau avec incorporation de technologies, option trop éloignée du type de pastoralisme pratiqué dans les Cévennes.

Mots-clés : ovin, système d'élevage, adaptation, moyens d'existence durables, région méditerranéenne

\section{Resumen}

Dedieu B., Pailleux J.-Y. Los caminos perdurables en la cría de ovejas en pastoreo en las Cevenas en Francia

En el contexto de la incertidumbre de las condiciones futuras, cuáles son los caminos perdurables? Describimos los métodos de larga duración en los que se apoyan los finqueros para desarrollar sus fincas o adaptarlas a su medio ambiente. Estos métodos se basan en escogencias relacionadas con aumentar el tamaño de la finca, especialización, técnicas utilizadas, mercadeo, proyección de deudas de producción e incorporación de tecnología. Los datos provienen de fincas ovejeras en las Cevenas, región pastoril Mediterránea del sur de Francia, basados en encuestas de trayectoria de familias, agricultura y manejo de ovejas durante 30 años (1982-2012). A pesar de que la agricultura ovina ha cambiado poco durante este periodo, se han identificado tres métodos de acción a largo plazo: una lógica de clan que permite a los hijos establecerse en la finca o en su proximidad; una lógica centrada en la tradición ovina con un enfoque en aumentar el tamaño del hato; y una lógica multifacética, por ejemplo se exploran dos o tres tipos de manejo ovino sucesivos o actividades domésticas combinadas. Las metodologías de acción identificadas fueron similares a las descritas en otros estudios, excepto que no incluyeron métodos basados en aumentar la productividad del hato mediante el uso de tecnologías, una opción demasiado lejana de la clase de pastoreo practicado en las Cevenas.

Palabras clave: ovino, sistema de explotación, adaptación, medios de vida sostenibles, región mediterránea 